\title{
DEVELOPMENT OF MATHEMATHICS STORYBOOK FOR CHILD GROUP B IN TK NEGERI PEMBINA SOUTH INDRALAYA

\author{
Oleh: \\ Syafdaningsih ${ }^{1}$, Ria Rosidah ${ }^{2}$ \\ Universitas Sriwijaya
}

\begin{abstract}
Research development has a view to produce story books mathematics. The development of story books mathematics it uses combination model of rowntree and evaluation tessmer. Model of rowntree consists of three stages, in the planning, developmental stage and the evaluation. At the evaluation an evaluation formative presented by tessmer consisting of five stage, in the self evaluation, experts review, one-toone evaluation, small group evaluation and field test. Using techniques data collection observation. From the experts review obtained the average score the assessment of the experts on the Book 1 of 3,90\% (category very valid), Book 2 of 3,90\% (category very valid), Book 3 of 3,90\% (category very valid), Book 4 of 3,90\% (category very valid). Phase one-to-one evaluation obtained the average observations children with Book 1 of $85 \%$ (category very good), Book 2 of 86\% (category very good), Book 3 of $87 \%$ (category very good), and Book 4 of $86 \%$ (category very good). The small group evaluaion obtained the average observation on the Book 1 of $88 \%$ (category very good), Books 2 of $90 \%$ (category very good), Book 3 of $91 \%$ (category very good), and Book 4 of $92 \%$ (category very good). At the field for observation test scores on the Book 1 of $95 \%$ (category very good), Books 2 of 95\% (category very good), Book 3 of 91\% (category very good), Books 4 of 95\% (category very good). Of all stages already done so it can be concluded that story books mathematics expressed valid, practical, and have an effect potential for children.
\end{abstract}

Keyword: story books, mathematics

\begin{abstract}
Abstrak: Pengembangan penelitian ini memiliki pandangan untuk menghasilkan bukubuku cerita matematika. Pengembangan buku cerita matematika menggunakan kombinasi model rowntree dan evaluasi tessmer. Model rowntree terdiri dari tiga tahap, dalam tahap perencanaan, tahap pengembangan dan evaluasi. Pada evaluasi evaluasi formatif yang disajikan oleh tessmer yang terdiri dari lima tahap, dalam evaluasi diri, ulasan ahli, evaluasi satu-ke-satu, evaluasi kelompok kecil dan uji lapangan. Menggunakan teknik observasi pengumpulan data. Dari tinjauan ahli diperoleh skor rata-rata penilaian ahli pada Buku 1 sebesar 3,90\% (kategori sangat berlaku), Buku 2 dari 3,90\% (kategori sangat valid), Buku 3 dari 3,90\% (kategori sangat valid), Buku 4 dari 3,90\% (kategori sangat valid). Tahap satu-ke-satu evaluasi diperoleh rata-rata pengamatan anak-anak dengan Buku 1 dari 85\% (kategori sangat baik), Buku 2 dari 86\% (kategori sangat baik), Buku 3 dari 87\% (kategori sangat baik), dan Buku 4 dari 86\% (kategori sangat bagus). Evaluasi kelompok kecil memperoleh rata-rata pengamatan pada Buku $188 \%$ (kategori sangat baik), Buku 2 dari 90\% (kategori sangat baik), Buku 3 dari 91\% (kategori sangat baik), dan Buku 4 dari 92\% ( kategori sangat bagus). Di lapangan untuk skor tes observasi pada Buku 1 dari 95\% (kategori sangat baik), Buku 2 dari 95\% (kategori sangat baik), Buku 3 dari 91\% (kategori sangat baik), Buku 4 dari 95\% (kategori sangat baik). Dari semua tahapan yang sudah dilakukan sehingga dapat disimpulkan bahwa buku cerita matematika dinyatakan valid, praktis, dan memiliki potensi efek bagi anak.
\end{abstract}

Kata Kunci: buku cerita, matematika

\footnotetext{
'Program Studi Pendidikan Guru Pendidikan Anak Usia Dini, Fakultas Keguruan dan Ulmu Pendidikan, Universitas Sriwijaya ${ }^{2}$ Program Studi Pendidikan Guru Pendidikan Anak Usia Dini, Fakultas Keguruan dan Ilmu Pendidikan, Universitas Sriwijaya, Email: riarasidah\$4国yahou.com
} 


\section{INTRODUCTION}

Law Number 20 Year 2003 on National Education System Article 1 point 14 states that Early Childhood Education (PAUD) is a coaching effort aimed at children from birth to age six years through giving stimulus education to assist growth and physical development and spiritual, so that children have readiness in entering further education, both formal education in school and non-formal. Along with the rapid development of Science and Technology (IPTEK) requires the ability to obtain and utilize as well as to improve the quality of education. The most decisive thing for the achievement of the quality of education is the process of learning that is implemented one of them through learning mathematics.

Until now there are still many students who feel mathematics as a difficult subject, not fun, even a very frightening learning for students. Marti cited Sundayana (2015: 2) argues that, although mathematics is considered to have a high degree of difficulty, everyone should learn it because it is a means to solve everyday problems. Such problem solving involves the use of information, the use of knowledge of the shape and size, and the use of knowledge about counting.

Susanto (2012: 98-99) says that one branch of mathematics is counting. Counting is the basis of some of the sciences used in everyday life such as addition, subtraction, division, or multiplication. So the ability to calculate can be introduced from early childhood through the game, the media and the right methods should not damage the pattern of child development which in this case the researchers create a medium for counting learning through the story in accordance with the objectives of curriculum 2013 Early Childhood Education in Government Regulation No 146 Year 2014 is to encourage the development of the potential of children to have the readiness to pursue further education that is in elementary school (SD). So it would not hurt if simple mathematics learning has been introduced to the Age of Kindergarten.

Early Childhood Education develops learning that involves 5 aspects of basic ability possessed by the child one of them is the aspect of cognitive development. According to Nugraha cited Elhumairoh (2015) Cognitive development is a process of thinking in the form of the ability of the brain to connect, assess, and consider something in obtaining information that includes the ability to count children. Counting is one part of mathematics, to create a learning process that will be sought by the child then what must be done by the teacher is how to math learning is fun for the Early Childhood.

Based on the observations of researchers in group B kindergarten Affairs Pembina South Indralaya, researchers found children aged 5-6 years in kindergarten group B still many who have not been able to recognize the concept of numbers, and the addition or reduction simply. This is because the learning activities of children B group counting each day only use magazine books containing student worksheet and children are asked to work on the student worksheet without any other activities, the book used does not refer to the themes in the curriculum, the book does not meet the criteria of a good book for children, the book used does not match the numerical learning indicators for children aged 5-6 years. At the time of observation, the children do the activity of counting the numbers on the poster/picture so it makes the child bored, it proves there are 5 children counting the numbers and 10 children who do not count when the teacher asks questions only a few children who answered. 
Based on the above problems, the researchers looked for other alternatives in the learning of counting children so as not to bore the learning of mathematics through stories and researchers trying to create a product in the form of math storybooks that are able to attract the attention of children and in accordance with the characteristics of children aged 56 years. In accordance with research conducted by Rosari, et al. (2014) entitled "Application of Story-Assisted Media Stories Picture Book Story To Improve Moral Behavior in Kindergarten Kecubung Desa Patas" Volume 2 Number 1 Year 2014. The results of the study explained that the average percent ability of moral values in cycle I of $63,60 \%$ are in a low category. The average ability of moral values in cycle II increased to $83.60 \%$ in the high category, this shows an increase from cycle I to cycle II by $20.00 \%$. It can be concluded that through the story-assisted method of the story book media can improve moral behavior in early childhood. Based on the above background, the researcher conducted a research entitled "Development of Mathematical Story Book for Children Group B in South Indralaya Pembina kindergarten"

\section{RESEARCH METHODS}

The type of research taken by researchers is a type of research development (Research and Development) with the following stages.

\section{Planning}

Needs and development analyzes are conducted to identify and identify the expected needs and development of children, by looking at the characteristics and indicators of achievement of child cognitive development for ages 5-6 years and describe the criteria of a good book for children tailored to themes in the curriculum.

\section{Development}

The development of the material is the determination of the story content in the mathematical storybook. The material must be in accordance with the needs of the child and the target to be achieved by the researcher is the mastery of the mathematics learning of children aged 5-6 years after using the book of mathematics. After compiling the contents of the story, the next step is to produce a prototype. The material has been compiled, will be converted into short story form, from the short story is then illustrated in the form of images.

The illustration of the story will then be given a description of it presented in the form of a story that contains the introduction of numbers, shapes, sizes, and symbols of numbers so that the prototype can be regarded as a mathematical story. In this case, researchers will develop four products in the form of a book of mathematical stories entitled: (1) I Like to Eat Vegetables. (2) Get on the Vehicle. (3) My Favorite Food Pempek. (4) My school. This math storybook is adapted to the themes of the first and second semesters. The result of this whole development stage is called Prototype 1.

\section{Evaluation \\ Self Evaluation}

At this stage, the assessment is done by the researchers themselves against the four products in the form of a book of mathematical stories that have been developed. Here the researcher evaluates itself all the books, in this case, is the image that has been developed, whether the picture is appropriate and clear, whether the color is interesting and whether the content of the story in accordance with the concept of learning mathematics for children aged 5-6 years.

\section{Expert Review}

The results of these four products (Prototype 1) developed on the basis of self-evaluation are awarded to experts to 
be validated. At this stage, the validator will see and evaluate the design of the four products that have been created. Validity test conducted is the validity of content (material) and book design. Validation results in the form of responses/comments and suggestions on the validation sheet will serve as the basis for revising the mathematical storybook (prototype 1).

\section{One-to-one Evaluation}

At this stage, the four products of math story books are tested on the child. Researchers chose three children at random to represent the target population of children with low, moderate, and high ability. The child is given a lesson with a revised prototype 1 . At the time of child learning process will be observed through the observation sheet that has been provided to see and assess directly the behavior or the process of the occurrence of a lesson using prototype 1 .

\section{Small Group Evaluation}

At this stage prototype, 2 was piloted on a small group of 9 children. Furthermore, the child is given a lesson with a revised prototype 2 . In the learning process, the child will be re-observed.

\section{Field Test}

At this stage, prototype 2 is tested on all children in the class. All children are given learning using math story books that have been through the stage of one-to-one evaluation and small group evaluation. At the time of learning, the child will be reobserved to see the child's activity for a mathematical storybook to have a potential effect on the child after being given the material by using a math storybook.

Data collection techniques used in this study are:

The Walkthrough cited Anggraini (2015) is a data validation involving several experts to evaluate the product as a basis for revising the initial product/prototype 1 .
The data collection instrument in this technique is to use the validation sheet provided to the expert or the validator. The data collected on this validation sheet is in the form of responses and suggestions on which the researcher base to revise the initial product/prototype. Data from the results of validation by the experts then discussed with the expert itself to obtain clarity of the product validation information results, so that researchers can use data validation results as a reference to revising the product/prototype until declared eligible for the trial.

Observation, according to Sugiyono (2015: 203) Observation is used to assess the behavior seen from the child's active in learning activities by using a book of mathematics stories that can be observed. In this research, to get observation data is done by seeing and assessing directly activity and behavior of child during learning process by using mathematics storybook. Observations were made during the one-to-one, small group, and field test stages, whether they were done well when using math storybooks.

The walkthrough results with experts are analyzed descriptively as input to revise the book. The input is written on the validation sheet. The validation sheet is given to the expert in the Likert scale. Sugiyono (2015: 135) Likert scale using four categories of answers are Very Good (SB), Good (B), Not Good (TB), and Very Not Good (STB) as shown in Table 3.4 below:

Validation results from the validator are presented in tabular form. Next look for the average score by using the formula as follows.

$$
x=\frac{\sum X}{N}
$$

(Sudjana, 2017: 109)

Type:

$\mathrm{X}=$ Average value

$\Sigma \mathrm{X}=$ Number of data values

$\mathrm{N}=$ Number of data 
Furthermore, the average obtained is adjusted according to the categories as seen in Table 1 below.

Table 1 Category Of Picture Validity

\begin{tabular}{c|c}
\hline Avg & Category \\
\hline $3,25-4,00$ & Very Valid \\
$2,50-3,24$ & Valid \\
$1,75-2,49$ & Not Valid \\
$1,00-1,74$ & Very Invalid \\
\hline
\end{tabular}

The results of the observation of the child during the test at the one-to-one evaluation stage, small group evaluation and field test were used to look at children's behavior during the learning process using this math storybook. Observation result data is presented in tabular form, then calculate the value of observation result using the following formula.

Percentage Value

$$
=\frac{\text { Gaining Score }}{\text { Max Score }} \times 100 \%
$$

(Sunarti \& Rahmawati, 2014: 191)

The value of the observation is converted into he defined category as in Table 2 below.

Table 2 Categories of Results Observation of Children Against the Use of Mathematical Stories Books

\begin{tabular}{c|c}
\hline Score (\%) & Category \\
\hline $80-100$ & Very Good \\
$70-79$ & Good \\
$60-69$ & Enough \\
\hline
\end{tabular}

\begin{tabular}{c|c}
$<60$ & Less \\
\hline
\end{tabular}

(Amirono \& Daryanto, 2016: 126)

\section{RESULT AND DISCUSSION}

Needs and development analysis is to see indicators of achievement of cognitive development of children aged 5-6 years and describe the criteria of a good book for children tailored to the themes that exist in the curriculum.

The material given to the children is the mathematics learning of children aged 5-6 years in the form of numbers, the introduction of the concept of addition and reduction in simple, size, shape, and symbol number.

After drafting the story, the next step is to produce a prototype. Draft stories that have been compiled have been equipped with pictures and edited to get the story in accordance with mathematics learning materials for children aged 5-6 years. The researcher produced four products in the form of a mathematics storybook with the title as follows. (1) I Love to Eat Vegetables. (2) Get on the Vehicle. (3) My Favorite Food Pempek. (4) My school. The overall result of this development stage is prototype 1 . At the development stage, an evaluation tool is also used to evaluate the mathematical storybook that has been made in terms of content/material and book design. Evaluation tools include content/material validation sheets, book designs, and observation sheets to assess children's behavior on the use of math storybooks. Prior to use, the evaluation tool is first checked by the supervisor.

The average result of expert review validation for the content / material aspects of Book 1 (I Like to Eat Vegetables) is 3.87 (very valid category), Book 2 (Come Up Vehicle) of 3.87 (very valid category), Book 3 ( Pempek My Favorite Food) of 3.87 (very valid category), and Book 4 (My School) of 3.87 (very valid category) and for the 
design of Book 1 (I Love Vegetables) of 3.93 (very valid category) Book 3 (Come on Vehicle) of 3.93 (very valid category), Book 3 (Pempek Makanan Kesukaanku) of 3.93 (very valid category), and Book 4 (My School) of 3.93 (very valid category) so the average expert validation result for Book 1, Book 2, Book 3 and Book 4 is 3.90 (highly valid category).

The average percentage of observations during the one-to-one evaluation phase of Book 1 (I Love Vegetables) was $85 \%$ (excellent category), Book 2 (Come on Vehicle) by $86 \%$ (excellent category), Book 3 (Pempek My Favorite Food) of $87 \%$ (excellent category), and Book 4 (My School) of $86 \%$ (excellent category) so it can be concluded that the use of four books of mathematical stories has a practical criteria for children.

The average percentage of observations during the small group evaluation phase of Book 1 (I Love Vegetables) was $88 \%$ (excellent category), Book 2 (Come on Vehicle) by 90\% (excellent category), Book 3 (Pempek Is My favorite Food) of 91\% (excellent category), and Book 4 (My School) $92 \%$ (excellent category) so it can be concluded that the use of four books of mathematical stories has a practical criteria for children.

The average percentage of observation results in the field test field of Book 1 (I Love Vegetables) is 95\% (excellent category), Book 2 (Come on Vehicle) 95\% (excellent category), Book 3 (Pempek Makanan Kesukaanku) of 91\% (excellent category), Book 4 (My School) of $95 \%$ (excellent category). These results suggest that math storybooks have a potential effect on children's understanding.

\section{CONCLUSION}

Mathematics storybook developed is valid based on the results of expert validation (expert review) so that this math storybook is suitable to be used as teaching material for learning mathematics. This can be seen from the average results of expert review Book 1, Book 2, Book 3, and Book 4 of 3.90 (very valid category).

To test the practicality of the book based on the results of the one-to-one evaluation phase in Book 1 of $85 \%$ (excellent category), Book 2 of $86 \%$ (excellent category), Book 3 of $87 \%$ (excellent category), and Book 4 amounted to $86 \%$ (excellent category) obtained by the value of child's observation on the use of math storybook. Based on the result of child observation on the use of mathematics textbook at small group evaluation stage get the average in Book 1 of $88 \%$ (excellent category), Book 2 of 90 (excellent category), Book 3 of $91 \%$ (excellent category), and Book 4 of 92\% (excellent category) so that based on the results of one-to-one evaluation and small group evaluation it can be stated that the mathematics storybook developed has been tested for its practicality.

To see the potential effects can be seen from the results of observation values in Book 1 of $95 \%$ (excellent category), Book 2 of $95 \%$ (excellent category), Book 3 of $91 \%$ (excellent category), Book 4 of $95 \%$ category is excellent). So it is stated that the mathematical storybook has a potential effect on children's understanding of learning mathematics.

\section{REFERENCES}

Amirono, M.T., \& Daryanto. (2016). Evaluasi dan Penilaian Pembelajaran Kurikulum 2013. Yogyakarta: Gava Media.

Anggraini. (2015). Pengembangan Media Layanan Klasikal Berbasis Cerita Bergambar Bidang Sosial-Pribadi dengan Materi Kesetiakawanan Sosial di Kelas IV SD Negeri 179 Palembang. Skripsi. Inderalaya: Universitas Sriwijaya.

Elhumairoh, R. (2015). Pengaruh Model Guided Inquiry Terhadap Kemampuan Sains Di Kelas B Tk Al-Kausar 
Indralaya. Skripsi. Inderalaya: FKIP Unsri.

Peraturan Menteri Pendidikan dan Kebudayaan Repulik Indonesia Nomor 146 Tahun 2014 tentang Kurikulum 2013 Pendidikan anak Usia Dini.

Rosari, Y. P. P., Agung, A. A. G., \& Ambara, D. P. (2014). Penerapan Metode Bercerita Berbantuan Media Buku Cerita Bergambar Untuk Meningkatkan Perilaku Moral Anak Kelompok B Di TK Kecubung Desa Patas. 2(1). e-Journal PG PAUD Universitas Pendidikan Ganesha.

Sudjana, N. (2017). Penilaian Hasil Proses Belajar Mengajar. Bandung: PT Remaja Rosdakarya.

Sugiyono. (2012). Metodologi Penelitian, Kualitatif, Kuantitatif, dan R \& D. Bandung: CV Alfabeta.

Sunarti., \& Rachmawati, S. (2014). Penilaian dalam Kurikulum 2013 Membantu Guru dan Calon Guru Mengetahui Langkah-Langkah Penilaian Pembelajaran. Yogyakarta: C.V Andi Offset.

Sundayana. R. (2015). Media dan Alat Peraga dalam Pembelajaran Matematika. Bandung: Alfabeta.

Susanto, A. (2012). Perkembangan Anak Usia Dini Pengantar dalam Berbagai Aspeknya. Jakarta: Kencana Prenada Media Group.

Undang-undang No 20 tahun 2003 pasal 1 ayat 14 . 